\title{
Effect of unilateral incisor tooth amputation on the glucose metabolism in submandibular glands of rats following sympathetic and parasympathetic denervation
}

\section{Efeito da amputação unilateral do incisivo inferior sobre o metabolismo da glicose em glândulas submandibulares de ratos submetidas a desnervação simpática e parassimpática}

\author{
Marinez ALMEIDA-DE-FARIA* \\ Jarbas A. BAUER* \\ Jose NICOLAU**
}

\begin{abstract}
ALMEIDA-DE-FARIA, M.; BAUER, J. A.; NICOLAU, J. Effect of unilateral incisor tooth amputation on the glucose metabolism in submandibular glands of rats following sympathetic and parasympathetic denervation. Pesq Odont Bras, v. 14, n. 1, p. 25-31, jan./mar. 2000.
\end{abstract}

\begin{abstract}
The autonomic nervous system is of major importance in the regulation of physiological functions of the salivary glands, including the sialadenotrophic process. It is well known that the secretory function as well as other functions in the salivary glands depend upon the energy produced in the gland. The acini volume density, some enzymes of the glucose metabolism, such as hexokinase, phosphofructokinase, pyruvate kinase, glucose-6-phosphate dehydrogenase and lactate dehydrogenase were evaluated following sympathetic and parasympathetic denervation of submandibular glands of rats, submitted to unilateral incisor amputation, five days after denervation. Sympathectomized glands submitted to amputation showed a reduction in the activity of hexokinase and phosphofructokinase-1, varying from 27.5 to $36.7 \%$ for hexokinase and from 22.8 to $38.4 \%$ for phosphofructokinase-1. Although no variation was observed in the enzymatic activity of parasympathectomized animals, the acini volume density showed a significant decrease.
\end{abstract}

UNITERMS: Denervation; Amputation; Enzymes; Glucose metabolism.

\section{INTRODUCTION}

In humans, the enlargement of the salivary glands, sialadenosis, is frequently associated with some pathologies such as, diabetes mellitus and hepatic diseases. The enlargement of the salivary glands can be experimentally induced in some laboratory animals by either chronic administration of sympathomimetic drugs, such as isoproterenol (IPR) ${ }^{6,24}$, or repeated amputations of the lower-incisor teeth $^{15,21,31,32}$. In either intervention, the development of the sialadenosis process is a function of an increased activity of the sympathetic nervous system. Comparing the enlargement caused by isoproterenol with that caused by the lower-incisor teeth amputations, we have, previously, shown differences in the glycolytic enzymes ${ }^{10}$ and in the adenine nucleotide contents ${ }^{19}$ in the submandibular salivary glands of rats. The periodic amputation of the lower and upper incisors of female rats has shown no differences in radioligand binding assays of $\alpha_{1}, \beta, \alpha_{2}$ receptors between control and experimental glands in terms of densities and affinities ${ }^{7}$.

Taking into consideration that the autonomic nervous system plays an important role in the development of the sialadenotrophic process we examined the effect of the sympathetic and parasympathetic denervation of the submandibular salivary glands of rats submitted to periodic amputations on some enzymes from the glycolytic and pentose-phosphate pathways.

\section{MATERIALS AND METHODS} Animals

Male rats of the Wistar strain (180-220 g) were kept in individual cages with water and food ad libitum. The animals were subjected to either sym-

*Institute of Biomedical Sciences; **Institute of Chemistry - University of São Paulo. 
ALMEIDA-DE-FARIA, M.; BAUER, J. A.; NICOLAU, J. Effect of unilateral incisor tooth amputation on the glucose metabolism in submandibular glands of rats following sympathetic and parasympathetic denervation. Pesq Odont Bras, v. 14, n. 1, p. 25-31, jan./mar. 2000.

pathetic or parasympathetic denervation followed by unilateral amputation of the lower left incisor tooth (AMPT). Five days after denervation, AMPT was performed every other day, by cutting down the tooth to the pulp, under light ether anesthesia. The body weight of each animal was recorded throughout the experimental period. The animals were divided into the following groups : (a) rats with AMPT after sympathetic denervation; (b) rats with AMPT after parasympathetic denervation; (c) rats with AMPT keeping the innervation intact and (d) rats submitted only to light ether anesthesia without AMPT.

\section{Denervations}

Denervations were carried out in the left submandibular salivary gland (SMG). Rats were anesthetized with an intraperitoneal injection (30 $\mathrm{mg} / \mathrm{Kg}$ body wt) of sodium pentobarbital. Sympathectomy was performed by removing the superior cervical ganglion and parasympathectomy by sectioning and removing a segment of about $5 \mathrm{~mm}$, from the proximal part of the lingual nerve. The right SMG was used as control. All the surgery procedure was carried out with the help of a stereoscopic microscope.

\section{Samples for Enzymatic Assay}

Twenty-four hours after the last AMPT, the animals were anesthetized with an intraperitoneal injection of $10 \%$ chloral hydrate $(300 \mathrm{mg} / \mathrm{kg}$ body wt) and perfused with $0.9 \% \mathrm{NaCl}$ solution. Immediately after perfusion the SMG were removed, freed from the adherent tissue and weighed. The glands were homogenized at $10 \%$ with $50 \mathrm{mmol} / 1$ imidazol buffer, $\mathrm{pH} 7.0$, containing $2 \mathrm{mmol} / 1$ EDTA and $1 \mathrm{mmol} / 1$ 2-mercaptoethanol, in a glass homogenizer with a Teflon pestle. After centrifugation of the homogenate at $12,350 \mathrm{~g}$ for $30 \mathrm{~min}$, the supernatant was used for the enzymatic and proteinic determinations.

\section{Histometric Studies}

For histometric studies the animals were anesthetized with an intraperitoneal injection of $10 \%$ chloral hydrate (300 mg/kg body weight), perfused with $4 \%$ para-formaldehyde solution in $0.1 \mathrm{~mol} / 1$

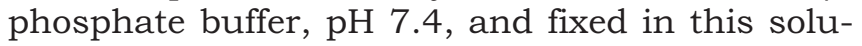
tion. The fixed samples were embedded in paraffin, sectioned at $5 \mu \mathrm{m}$ and submitted to $\mathrm{HE}$ staining. Histometric evaluation was made by counting the number of acini in 5 randomly selected view-field from sections of each examined gland, with the help of an ocular grid.

\section{Enzyme Assays}

Enzymatic activity of the supernatants was assayed by changes in absorption at $340 \mathrm{~nm}$ due to reduction of NADP or oxidation of NADH. The reaction was initiated by adding the homogenate supernatant to the reaction mixture in the cuvette and the absorbance was monitored for $10 \mathrm{~min}$, at $25^{\circ} \mathrm{C}$ in a Beckman-DU spectrophotometer, using a $1 \mathrm{ml}$ cuvette with $1 \mathrm{~cm}$ path length. The specific activity was expressed in U/mg protein. One unit of enzymatic activity corresponds to the amount of enzyme that converts $1 \mu \mathrm{mol}$ of substrate per minute. Enzymatic activity was measured as follows: Hexokinase (HK,EC 2.7.1.1) in a reaction medium containing $50 \mathrm{mmol} / 1$ imidazol buffer, $\mathrm{pH}$ 7.2, $5 \mathrm{mmol} / 1 \mathrm{MgCl}_{2}, 5 \mathrm{mmol} / 1 \mathrm{ATP}, 1 \mathrm{mmol} / 1$ glucose, $0.4 \mathrm{mmol} / 1 \mathrm{NADP}$ and $0.3 \mathrm{U} / \mathrm{ml}$ Glucose-6-phosphate dehydrogenase ${ }^{29}$; Phosphofructokinase-1 (PFK, EC 2.7.1.11) in a medium containing $50 \mathrm{mmol} / 1$ triethanolamine buffer, pH 7.0, $2 \mathrm{mmol} / 1$ EDTA, $0.5 \mathrm{mmol} / 1$ fructose-6-phosphate, $0.65 \mathrm{mmol} / 1 \mathrm{NADH}, 0.4 \mathrm{U} / \mathrm{ml}$ aldolase, $0.08 \mathrm{U} / \mathrm{ml}$ triosephosphate isomerase and $0.08 \mathrm{U} / \mathrm{ml}$ glycerophosphate dehydrogenase ${ }^{18}$; Pyruvate kinase ( PK, EC 2.7.1.40) in a medium containing, $50 \mathrm{mmol} / 1$ imidazol buffer, $\mathrm{pH}$ 7.2, $5 \mathrm{mmol} / 1 \mathrm{MgCl}_{2}, 0.1 \mathrm{~mol} / 1 \mathrm{KCl}, 1 \mathrm{mmol} / 1 \mathrm{ADP}$, $0.15 \mathrm{mmol} / \mathrm{L} \mathrm{NADH}, 2 \mathrm{mmol} / 1$ phosphoenolpyruvate and $0.9 \mathrm{U} / \mathrm{ml}$ lactate dehydrogenase ${ }^{16}$; Lactate dehydrogenase (LDH, EC 1.1.1.27) in a reaction mixture containing $49.5 \mathrm{mmol} / 1$ phosphate buffer, $\mathrm{pH} 7.5,0.6 \mathrm{mmol} / 1$ pyruvate and $0.18 \mathrm{mmol} / 1 \quad \mathrm{NADH}^{3}$; Glucose-6-phosphate dehydrogenase (G-6-PD, EC 1.1.1.49) in a reaction medium containing $0.1 \mathrm{~mol} / 1$ tris- $\mathrm{HCl}$ buffer, $\mathrm{pH} 7.4,20 \mathrm{mmol} / 1 \mathrm{MgCl}_{2}, 0.1 \mathrm{mmol} / 1 \mathrm{NADP}$ and $5.5 \mathrm{mmol} / 1$ glucose-6-phosphate ${ }^{11}$.

\section{Protein Determination}

Protein was estimated in the supernatant fraction by the method of LOWRY et al. ${ }^{17}$ using bovine serum albumin as standard.

\section{Statistical analysis}

Values were expressed as means $\pm \mathrm{SD}$, and statistical analyses were carried out using a repeated-measure ANOVA. Differences between means were then analysed for statistical significance using the multiple comparison of Student-Newman-Keus ${ }^{1}$. Differences between means were considered to be significant at the level of $\mathrm{P}<0.05$. 
ALMEIDA-DE-FARIA, M.; BAUER, J. A.; NICOLAU, J. Effect of unilateral incisor tooth amputation on the glucose metabolism in submandibular glands of rats following sympathetic and parasympathetic denervation. Pesq Odont Bras, v. 14, n. 1, p. 25-31, jan./mar. 2000.

\section{RESULTS}

Sympathectomized rats submitted to AMPT showed a reduction in the activity of $\mathrm{HK}$ and PFK-1, varying from 27.5 to $36.7 \%$ for $\mathrm{HK}$ and from 22.8 to $38.4 \%$ for PFK-1 (Table 1). No variation in the activity of the other studied enzymes, PK, LDH and G-6-PD, was observed in the SMG of sympathectomized animals.

In SMG of parasympathectomized animals no variation was observed in the activity of the studied enzymes, indicating that the glycolytic and the pentose-phosphate pathways were not influenced by the parasympathetic branch of the autonomic nervous system (Table 2). When the innervation was kept intact, no alteration was observed in the activity of enzymes from the SMG of animals submitted to AMPT (Table 3).

Histometric studies (Table 4) showed no difference between the SMG from the control and sympathectomized animals. However, the parasympathectomized glands showed a statistically significant decrease in the volume density of the acini, which varied from about $5 \%$ for one AMPT to about $24.5 \%$ for the six AMPT group. On the other hand, animals with intact innervation presented a statistically significant increase in the volume density of acini when compared to that of the control, which varied from about $8 \%$ for three AMPT to about $15 \%$ for the six AMPT group (Table 4).

\section{DISCUSSION}

It is important to emphasize that the biologic model used in the present investigation presents some differences in relation to those described elsewhere ${ }^{14,27,33}$. We have used unilateral amputation of the left lower incisor tooth instead of bilateral AMPT. Another difference is related to the time between denervation and the beginning of the AMPT. We started AMPT five days after denervation while others started it within a period not longer than 24 hours.

It is well known that the salivary glands develop atrophy when submitted to parasympathetic denervation, however this phenomenon is reversed by AMPT of the lower incisor teeth ${ }^{14,27,33}$. In our study, the AMPT was not able to reverse the atrophy of SMG caused by parasympathectomy. It is possible that (a) when we started the AMPT the glands were already atrophied and (b) the stimulus produced by unilateral amputation was not sufficient to reverse the existing atrophy.

TABLE 1 - Effect of unilateral incisor amputation on enzymes of the glucose metabolism following sympathetic denervation of submandibular salivary glands of rats (mean $\pm \mathrm{SD}$; $\mathrm{C}=$ control group; $\mathrm{E}=$ group with sympathetic denervation and amputation of the incisor tooth; in parenthesis is the number of animals; the asterisks indicate statistically significant by the Student-Newman-Keus test, $\mathrm{p}<0.05$ ).

\begin{tabular}{|c|c|c|c|c|c|c|c|c|c|c|}
\hline \multirow{2}{*}{$\begin{array}{l}\text { Number } \\
\text { of AMPT }\end{array}$} & \multicolumn{2}{|c|}{$\begin{array}{c}\mathrm{HK} \\
\text { (mU/mg of protein) }\end{array}$} & \multicolumn{2}{|c|}{$\begin{array}{c}\text { PFK-1 } \\
\text { (mU/mg of protein) }\end{array}$} & \multicolumn{2}{|c|}{$\begin{array}{c}\text { PK } \\
\text { (U/mg of protein) }\end{array}$} & \multicolumn{2}{|c|}{$\begin{array}{c}\text { LDH } \\
\text { (U/mg of protein) }\end{array}$} & \multicolumn{2}{|c|}{$\begin{array}{c}\text { G6PD } \\
\text { (mU/mg of protein) }\end{array}$} \\
\hline & $\mathrm{C}$ & $\mathrm{E}$ & $\mathrm{C}$ & $\mathrm{E}$ & $\mathrm{C}$ & $\mathrm{E}$ & $\mathrm{C}$ & $\mathrm{E}$ & $\mathrm{C}$ & $\mathrm{E}$ \\
\hline \multirow{2}{*}{1} & $17.45(7)$ & $11.57(7)^{*}$ & $16.77(8)$ & $12.80(7)^{*}$ & $0.24(6)$ & $0.25(7)$ & $0.59(8)$ & $0.60(8)$ & $17.89(7)$ & $14.30(7)$ \\
\hline & \pm 4.71 & \pm 2.68 & \pm 3.91 & \pm 1.59 & \pm 0.04 & \pm 0.07 & \pm 0.11 & \pm 0.09 & \pm 3.34 & \pm 3.05 \\
\hline \multirow{2}{*}{2} & $19.07(8)$ & $13.01(6)^{*}$ & $21.49(8)$ & $13.22(7)^{*}$ & $0.34(8)$ & $0.32(7)$ & $0.43(8)$ & $0.41(8)$ & $22.60(7)$ & $19.60(7)$ \\
\hline & \pm 4.13 & \pm 2.41 & \pm 5.19 & \pm 3.25 & \pm 0.01 & \pm 0.05 & \pm 0.10 & \pm 0.07 & \pm 5.14 & \pm 4.83 \\
\hline \multirow{2}{*}{3} & $17.97(6)$ & $12.95(6)^{*}$ & $17.24(6)$ & $11.81(6)^{*}$ & $0.25(6)$ & $0.24(6)$ & $0.61(7)$ & $0.55(7)$ & $16.73(6)$ & $14.82(6)$ \\
\hline & \pm 3.59 & \pm 4.59 & \pm 4.33 & \pm 2.15 & \pm 0.04 & \pm 0.05 & \pm 0.09 & \pm 0.04 & \pm 2.13 & \pm 1.72 \\
\hline \multirow{2}{*}{4} & $16.14(6)$ & $13.25(6)^{*}$ & $20.35(6)$ & $13.92(6) *$ & $0.34(6)$ & $0.31(6)$ & $0.55(8)$ & $0.49(8)$ & $18.53(6)$ & $17.28(6)$ \\
\hline & \pm 3.26 & \pm 1.06 & \pm 4.72 & \pm 3.14 & \pm 0.08 & \pm 0.09 & \pm 0.06 & \pm 0.07 & \pm 3.74 & \pm 4.00 \\
\hline \multirow{2}{*}{5} & $19.8(8)$ & $13.28(7)^{*}$ & 22.00 & $13.59(8)^{*}$ & $0.30(6)$ & $0.28(8)$ & $0.56(8)$ & $0.51(8)$ & $22.54(7)$ & $18.51(8)$ \\
\hline & \pm 4.52 & \pm 2.00 & \pm 3.81 & \pm 2.32 & \pm 0.08 & \pm 0.06 & \pm 0.07 & \pm 0.09 & \pm 4.99 & \pm 4.03 \\
\hline \multirow{2}{*}{6} & $17.49(7)$ & $12.67(7)^{*}$ & $17.97(7)$ & $13.83(7)^{*}$ & $0.32(7)$ & $0.31(7)$ & $0.48(8)$ & $0.53(8)$ & $18.81(7)$ & $19.65(7)$ \\
\hline & \pm 4.44 & \pm 2.07 & \pm 4.49 & \pm 1.00 & \pm 0.01 & \pm 0.09 & \pm 0.05 & \pm 0.09 & \pm 4.10 & \pm 4.26 \\
\hline
\end{tabular}


ALMEIDA-DE-FARIA, M.; BAUER, J. A.; NICOLAU, J. Effect of unilateral incisor tooth amputation on the glucose metabolism in submandibular glands of rats following sympathetic and parasympathetic denervation. Pesq Odont Bras, v. 14, n. 1, p. 25-31, jan./mar. 2000.

Histometrical analysis showed a reduction in the acini volume density of the parasympathectomized glands. The magnitude of this reduction increased with the number of AMPT. In contrast, non denervated glands showed an increase in the acini volume density, while no alterations were observed in the sympathectomized animals. Therefore, parasympathetic innervation responds for the trophism of SMG, and the development of sialadenosis is dependent upon the integrity of the autonomic nervous system ${ }^{14,15}$. The enlargement of salivary glands caused by AMPT leads to hypertrophy and hyperplasia ${ }^{4,26}$. No hypertrophy was observed in the sympathectomized SMG after AMPT. This agrees with the reported results showing that the effect of AMPT is mediated via sympathetic branch of the autonomic nervous system ${ }^{5}$. In animals with intact innervation of SMG the hypertrophy was present after the third AMPT. In all groups, the observed difference was caused by alterations in the volume of acini (atrophy or hypertrophy), which agrees with the data already reported $^{21,26,32}$.

The results clearly show that sympathetic denervation caused a coordinated reduction in the enzymatic activity of HK and PFK-1, key enzymes of the glycolytic pathway. The role of HK and PFK-1 in regulating the carbohydrate metabolism is well known. HK, the first enzyme that catalyzes phosphorylation of glucose, may be regulated by a variety of metabolites ${ }^{23}$, and by its distribution between the mitochondrial and soluble fractions ${ }^{34}$. The redistribution of the enzyme between the mitochondrial and soluble fractions may have some metabolic signification in sialadenosis caused by IPR, but not by AMPT, since this sialadenotrophic procedure does not interfere in its redistribution ${ }^{10}$.

On the other hand, the activity of PFK-1, the enzyme that phosphorylates fructose-6-phophate, may be regulated by a series of allosteric effectors, substrates and products ${ }^{28}$ as well as by Fructose-2,6-bisphosphate ${ }^{13}$. In the SMG of rats, PFK-1 is sinergically regulated by ATP, fructose-6-phosphate and fructose-2,6-bisphosphate ${ }^{12,25}$. This metabolite (fructose-2,6-bisphosphate) is a potent effector in the regulation of the allosteric nature of PFK-1. At the same time that it stimulates the activity of PFK-1, it inhibits the activity of fructose-1,6-bisphosphatase ${ }^{22,30}$. The enzyme fructose-1,6-bisphosphatase is found in various tissues, especially in those with a pronounced neoglycogenic process. It is also present in SMG,

TABLE 2 - Effect of unilateral incisor amputation on the enzymatic activity of the glucose metabolism following parasympathetic denervation of submandibular salivary glands of rats (mean $\pm \mathrm{SD} ; \mathrm{C}=\mathrm{control}$ group; $\mathrm{E}=$ group with parasympathetic denervation and amputation of the incisor tooth; in parenthesis is the number of animals ).

\begin{tabular}{|c|c|c|c|c|c|c|c|c|c|c|}
\hline \multirow{2}{*}{$\begin{array}{l}\text { Number } \\
\text { of AMPT }\end{array}$} & \multicolumn{2}{|c|}{$\begin{array}{c}\mathrm{HK} \\
(\mathrm{mU} / \mathrm{mg} \text { of protein) }\end{array}$} & \multicolumn{2}{|c|}{$\begin{array}{c}\text { PFK-1 } \\
(\mathrm{mU} / \mathrm{mg} \text { of protein) }\end{array}$} & \multicolumn{2}{|c|}{$\begin{array}{c}\text { PK } \\
\text { (U/mg of protein) }\end{array}$} & \multicolumn{2}{|c|}{$\begin{array}{c}\text { LDH } \\
\text { (U/mg of protein) }\end{array}$} & \multicolumn{2}{|c|}{$\begin{array}{c}\text { G6PD } \\
\text { (mU/mg of protein) }\end{array}$} \\
\hline & $\mathrm{C}$ & E & $\mathrm{C}$ & $\mathrm{E}$ & $\mathrm{C}$ & $\mathrm{E}$ & $\mathrm{C}$ & $\mathrm{E}$ & $\mathrm{C}$ & $\mathrm{E}$ \\
\hline & $19.44(7)$ & $14.85(8)$ & $15.48(8)$ & 14.22 & $0.24(8)$ & $0.20(7)$ & $0.44(8)$ & 0.41 & $19.89(6)$ & $18.80(8)$ \\
\hline & \pm 6.08 & \pm 1.86 & \pm 4.29 & \pm 3.84 & \pm 0.07 & \pm 0.04 & \pm 0.06 & \pm 0.05 & \pm 2.99 & \pm 2.11 \\
\hline \multirow{2}{*}{2} & $20.29(7)$ & 17.39 & $19.39(6)$ & 16.08 & $0.28(9)$ & 0.23 & $0.57(6)$ & 0.53 & $16.19(7)$ & $15.35(8)$ \\
\hline & \pm 3.16 & \pm 2.89 & \pm 2.92 & \pm 3.31 & \pm 0.07 & \pm 0.05 & \pm 0.10 & \pm 0.11 & \pm 2.59 & \pm 3.37 \\
\hline \multirow{2}{*}{3} & $20.31(7)$ & $17.68(7)$ & $13.83(9)$ & $13.30(9)$ & $0.27(11)$ & $0.23(9)$ & $0.66(6)$ & $0.60(6)$ & $17.002(7)$ & $17.09(7)$ \\
\hline & \pm 2.98 & \pm 2.77 & \pm 2.67 & \pm 2.29 & \pm 0.03 & \pm 0.02 & \pm 0.04 & \pm 0.07 & \pm 2.30 & \pm 2.92 \\
\hline \multirow{2}{*}{2} & $16.11(9)$ & $14.37(9)$ & $16.06(7)$ & $14.37(7)$ & $0.21(10)$ & $0.21(8)$ & $0.44(8)$ & $0.49(7)$ & $17.67(10)$ & 17.23 \\
\hline & \pm 2.56 & \pm 2.65 & \pm 2.93 & \pm 3.54 & \pm 0.05 & \pm 0.04 & \pm 0.09 & \pm 0.1 & \pm 3.45 & \pm 2.97 \\
\hline \multirow{2}{*}{5} & $14.41(7)$ & $17.33(7)$ & $15.07(6)$ & $15.42(7)$ & $0.25(7)$ & $0.24(7)$ & $0.45(7)$ & $0.57(7)$ & $14.84(7)$ & $16.78(7)$ \\
\hline & \pm 3.53 & \pm 4.87 & \pm 3.63 & \pm 2.83 & \pm 0.04 & \pm 0.05 & \pm 0.10 & \pm 0.13 & \pm 3.26 & \pm 4.19 \\
\hline & $14.62(5)$ & $17.48(5)$ & $16.91(5)$ & $13.40(5)$ & $0.20(5)$ & $0.18(5)$ & $0.45(5)$ & $0.45(5)$ & $13.09(5)$ & $13.58(5)$ \\
\hline & \pm 4.62 & \pm 3.93 & \pm 2.54 & \pm 2.59 & \pm 0.04 & \pm 0.04 & \pm 0.12 & \pm 0.09 & \pm 3.62 & \pm 4.02 \\
\hline
\end{tabular}


ALMEIDA-DE-FARIA, M.; BAUER, J. A.; NICOLAU, J. Effect of unilateral incisor tooth amputation on the glucose metabolism in submandibular glands of rats following sympathetic and parasympathetic denervation. Pesq Odont Bras, v. 14, n. 1, p. 25-31, jan./mar. 2000.

TABLE 3 - Effect of unilateral incisor amputation on the enzymatic activity of the glucose metabolism in intactly innervated submandibular salivary glands (mean $\pm \mathrm{SD} ; \mathrm{C}=$ control group; $\mathrm{E}=$ group with incisor tooth amputation; in parenthesis is the number of animals).

\begin{tabular}{|c|c|c|c|c|c|c|c|c|c|c|}
\hline \multirow{2}{*}{$\begin{array}{l}\text { Number of } \\
\text { AMPT }\end{array}$} & \multicolumn{2}{|c|}{$\begin{array}{c}\text { HK } \\
\text { (mU/mg of protein) }\end{array}$} & \multicolumn{2}{|c|}{$\begin{array}{c}\text { PFK-1 } \\
\text { (mU/mg of protein) }\end{array}$} & \multicolumn{2}{|c|}{$\begin{array}{c}\text { PK } \\
(\mathrm{U} / \mathrm{mg} \text { of protein) }\end{array}$} & \multicolumn{2}{|c|}{$\begin{array}{c}\mathrm{LDH} \\
\text { (U/mg of protein) }\end{array}$} & \multicolumn{2}{|c|}{$\begin{array}{c}\text { G6PD } \\
\text { (mU/mg of protein) }\end{array}$} \\
\hline & $\mathrm{C}$ & $\mathrm{E}$ & $\mathrm{C}$ & $\mathrm{E}$ & $\mathrm{C}$ & $\mathrm{E}$ & $\mathrm{C}$ & $\mathrm{E}$ & $\mathrm{C}$ & $\mathrm{E}$ \\
\hline \multirow{2}{*}{1} & $15.63(8)$ & $16.13(8)$ & $15.92(6)$ & $15.15(7)$ & $0.26(6)$ & $0.27(6)$ & $0.59(8)$ & $0.60(9)$ & $16.48(8)$ & $15.82(8)$ \\
\hline & \pm 2.93 & \pm 4.21 & \pm 3.93 & \pm 1.35 & \pm 0.052 & \pm 0.03 & \pm 0.11 & \pm 0.09 & \pm 4.36 & \pm 3.45 \\
\hline 2 & \pm 3.68 & \pm 4.31 & \pm 2.11 & \pm 3.31 & \pm 0.009 & \pm 0.03 & \pm 0.10 & \pm 0.074 & \pm 3.96 & \pm 2.98 \\
\hline \multirow{2}{*}{3} & $18.42(7)$ & $17.82(7)$ & $15.74(7)$ & $14.91(7)$ & $0.24(7)$ & $0.25(7)$ & $0.61(7)$ & $0.55(7)$ & $16.07(7)$ & $15.41(7)$ \\
\hline & \pm 3.31 & \pm 1.48 & \pm 1.91 & \pm 2.14 & \pm 0.032 & \pm 0.02 & \pm 0.087 & \pm 0.04 & \pm 2.34 & \pm 1.20 \\
\hline 4 & $16.44(8)$ & $14.26(8)$ & $14.52(8)$ & $14.411(8)$ & $0.200(7)$ & $0.21(8)$ & $0.55(8)$ & $0.49(8)$ & $16.87(8)$ & $15.88(8)$ \\
\hline 5 & \pm 2.08 & \pm 2.74 & \pm 4.53 & \pm 2.75 & \pm 0.04 & \pm 0.05 & \pm 0.068 & \pm 0.09 & \pm 1.72 & \pm 2.68 \\
\hline \multirow{2}{*}{6} & $14.61(8)$ & $15.54(8)$ & $14.97(7)$ & $15.42(8)$ & $0.24(8)$ & 0.25 & $0.47(8)$ & $0.53(8)$ & $15.56(8)$ & $16.22(8)$ \\
\hline & \pm 3.96 & \pm 3.91 & \pm 3.44 & \pm 3.10 & \pm 0.02 & \pm 0.03 & \pm 0.045 & \pm 0.09 & \pm 3.59 & \pm 2.99 \\
\hline
\end{tabular}

TABLE 4 - Effect of unilateral amputation on the acini volume density following sympathetic and parasympathetic denervation of submandibular salivary glands of rats (mean $\pm \mathrm{SD} ; \mathrm{C}=$ control group; $\mathrm{E}=$ groups with gland denervation and incisor amputation; in parenthesis is the number of animals; the asterisks indicate statistically significant by the Student-Newman-Keus test, $\mathrm{p}<0.05)$.

\begin{tabular}{|c|c|c|c|c|c|c|}
\hline \multirow{2}{*}{$\begin{array}{l}\text { Number of } \\
\text { AMPT }\end{array}$} & \multicolumn{2}{|c|}{ Parasympathectomized } & \multicolumn{2}{|c|}{ Sympathectomized } & \multicolumn{2}{|c|}{ Intact innervation } \\
\hline & $\mathrm{C}$ & $\mathrm{E}$ & $\mathrm{C}$ & $\mathrm{E}$ & $\mathrm{C}$ & $\mathrm{E}$ \\
\hline \multirow{2}{*}{1} & $49.47(15)$ & $47.08(15)^{*}$ & $50.07(15)$ & $49.87(15)$ & $50.13(15)$ & $49.73(15)$ \\
\hline & \pm 4.67 & \pm 4.716 & \pm 7.76 & \pm 6.25 & \pm 6.62 & \pm 5.97 \\
\hline \multirow{2}{*}{3} & $48.80(15)$ & $43.00(15)^{*}$ & $44.33(15)$ & $44.87(15)$ & $47.80(15)$ & $49.40(15)$ \\
\hline & \pm 4.02 & \pm 4.240 & \pm 6.88 & \pm 6.69 & \pm 3.49 & \pm 5.21 \\
\hline \multirow{2}{*}{3} & $47.20(15)$ & $40.60(15)^{*}$ & $46.13(15)$ & $43.60(15)$ & $48.00 *(15)$ & $52.27(15)^{*}$ \\
\hline & \pm 7.13 & \pm 4.98 & \pm 3.14 & \pm 8.82 & \pm 4.04 & \pm 5.42 \\
\hline \multirow{2}{*}{4} & $47.46(15)$ & $41.67(15)^{*}$ & $50.53(15)$ & $50.40(15)$ & $49.33(15)$ & $54.19(15)^{*}$ \\
\hline & \pm 5.57 & \pm 5.25 & \pm 5.65 & \pm 8.73 & \pm 3.52 & \pm 5.504 \\
\hline \multirow{2}{*}{5} & $48.26(15)$ & $40.86(15)^{*}$ & $48.87(15)$ & $50.80(15)$ & 46.47 (15) & $50.33(15)^{*}$ \\
\hline & \pm 9.30 & \pm 8.90 & \pm 6.83 & \pm 6.30 & \pm 3.58 & \pm 3.77 \\
\hline \multirow{2}{*}{6} & $40.90(15)$ & $30.90(15)^{*}$ & $48.00(15)$ & $47.40(15)$ & $46.60(15)$ & $53.67(15)^{*}$ \\
\hline & \pm 4.22 & \pm 4.04 & \pm 8.30 & \pm 8.21 & \pm 2.69 & \pm 3.27 \\
\hline
\end{tabular}


ALMEIDA-DE-FARIA, M.; BAUER, J. A.; NICOLAU, J. Effect of unilateral incisor tooth amputation on the glucose metabolism in submandibular glands of rats following sympathetic and parasympathetic denervation. Pesq Odont Bras, v. 14, n. 1, p. 25-31, jan./mar. 2000.

however its activity is very low and does not vary with starvation, so that it may be concluded that in this gland the neoglycogenic process is not operant $\mathrm{t}^{20}$. Therefore, it is our belief that, in salivary glands, the role played by fructose-2,6bisphosphate, is the activation of PFK-1. Previous results from our laboratory (manuscript in preparation) have shown a reduction of fructose-2,6-bisphosphate content and PFK-2 activity in submandibular glands of rats treated with the beta adrenergic agonist IPR. PFK-2 is a bi-functional enzyme that catalyses the synthesis and degradation of fructose-2,6-bisphosphate. The kinase activity is due to the dephosphorylated form while the phosphatase activity is due to the phosphorylated form ${ }^{2,8}$.

Considering that the mechanism of AMPT involves the beta adrenoceptor stimulation ${ }^{5,26}$ and that the beta adrenoceptor stimulation induces activation of the adenyl cyclase-cAMP-protein kinase system, how can one explain the reduced activity of the enzyme PFK-1 in sympathectomized glands? A possible explanation is the following: we started AMPT five days after denervation so that the axons were already degenerated. The absence of axons leads to an increased sensitivity of the parenchymal cells to stimulating agents'. The supersensitivity may trigger the cAMP-adenyl cyclase system, influencing the activity of PFK-1, with the AMPT procedure.

Considering that enzymes may be used as markers of metabolic events, variation in the activity of glucose-6-phosphate dehydrogenase was expected. However, our results did not show variation in the specific activity of this enzyme, which agrees with the results of previous studies in rats, performed in our laboratory ${ }^{10}$.

Despite the pronounced atrophy caused by parasympathectomy, the activity of the key enzymes of the glycolytic flow did not show alterations, presenting values comparable to those of the control group.

Although parasympathectomy may be considered responsible for the maintenance of the glandular mass, it does not exert influence on the activity of the key enzymes of the glycolytic pathway. Only the sympathectomized glands presented reduction in the activity of HK and PFK-1. AMPT was not able to promote the enlargement of the denervated glands.

\section{ACKNOWLEDGMENTS}

This work was financially supported by FAPESP and CNPq. J.N. is recipient of a fellowship from CNPq.

\footnotetext{
ALMEIDA-DE-FARIA, M.; BAUER, J. A.; NICOLAU, J. Efeito da amputação unilateral do incisivo inferior sobre o metabolismo da glicose em glândulas submandibulares de ratos submetidas a desnervação simpática e parassimpática. Pesq Odont Bras, v. 14, n. 1, p. 25-31, jan./mar. 2000.
}

\begin{abstract}
O sistema nervoso autônomo é de grande importância na regulação da fisiologia das glândulas salivares, incluindo o processo sialadenotrófico. Já é bem conhecido o fato de que a função secretora, bem como, outras funções desempenhadas pelas glândulas salivares dependem de energia produzida nas glândulas. A histometria dos ácinos, algumas enzimas do metabolismo de carboidratos como, hexoquinase, fosfofrutoquinase-1, piruvato quinase, glicose-6-fosfato desidrogenase e lactato desidrogenase foram avaliados na glândula submandibular de ratos com desnervação simpática e parassimpática, submetidos a amputação unilateral dos dentes incisivos, cinco dias após a desnervação. Nas glândulas simpatectomizadas submetidas a amputação dos incisivos observou-se uma redução nas atividades da hexoquinase $(27,5-36,7 \%)$ e da fosofofrutoquinase-1 $(22,8-38,4 \%)$. Embora, nehuma variação foi observado nas atividades enzimáticas, houve uma redução significante do volume acinar.
\end{abstract}

UNITERMOS: Desnervação; Amputação; Enzimas; Metabolismo de carboidratos.

\section{BIBLIOGRAPHIC REFERENCES}

1. ARMITAGE, P. Comparison of several groups. In Statistical Methods in Medical Research. $2^{\text {nd }}$. Oxford: Blackwell Scientific Publications, 1973. p. 202-207.

2. BARTRONS, R.; HUE, L.; VAN SCAFTINGEN, E. et al. Hormonal control of fructose-2,6-bisphosphate concentration in isolated rat hepatocytes. Biochem J, v. 214, p. 829-837, 1983.
3. BERGMEYER, H. U.; BERNT, E. Lactate dehydrogenase. UV-assay with pyruvate and NADH. In Bergmeyer, H.U. (edit.) Methods of enzymatic analysis, $2^{\text {nd }}$. New York: Verlag Chemie, 1974. v. 4. p. 574-579.

4. BOSHELL, J. L.; PENNINGTON, C. Histological observations on the effect of isoproterenol on regenerating submandibular glands of the rat. Cell Tissue Res, v. 213, p. 411-416, 1980.

5. BRENNER, G. M.; STANTON, H. C. Adrenergic mecha- 
ALMEIDA-DE-FARIA, M.; BAUER, J. A.; NICOLAU, J. Effect of unilateral incisor tooth amputation on the glucose metabolism in submandibular glands of rats following sympathetic and parasympathetic denervation. Pesq Odont Bras, v. 14, n. 1, p. 25-31, jan./mar. 2000.

nisms responsible for submandibular salivary gland hypertrophy in the rat. J Parmacol Exp Ther, v. 173, p. 166-175, 1970.

6. BROWN-GRANT, K. Enlargement of salivary gland in mice treated with isopropylnoradrenaline. Nature, v. 191, p. 1076-1078, 1961.

7. CHIARENZA, A. A.; ElVERDiN, J. C.; GAMBA, C. A. B. et al. Adrenergic receptors and secretory responses of the rat submandibular salivary gland after periodic incisor reduction. Archs Oral Biol, v. 43, p. 262-267, 1998

8. El MAGHRABI, M. R.; CLAUS, T. H.; PILKIS, J.; PILKIS, S. J. Partial purification of a rat liver enzyme that catalyzes the formation of fructose-2,6-bisphosphate. Biochem Biophys Res Commun, v. 101, p. 1071-1077, 1981.

9. EMMELIN, N. Actions of transmitters on the responsiveness of effector cells. Experientia, v. 21, p. 57-65, 1965.

10. FERREIRA, F. D.; NICOLAU, J. Changes in glucose metabolism in submandibular salivary glands of rats after isoproterenol or incisor tooth amputation. Archs Oral Biol, v. 32, p. 499- 503, 1987.

11. GLOCK, G. E.; McLEAN, P. Further studies on the properties and assay of glucose-6-phosphate dehydrogenase of rat liver. Biochem J, v. 55, p. 400-408, 1953.

12. HAMANO, E.; YAMAZAKI, T.; SAITO, M. et al. Comparison of phosphofructokinases in submandibular glands of immature and adults rats. Comp Biochem hysiol, v. 94B, p. 697-701, 1989.

13. HERS, H. G.; HUE, L.; VAN SCHAFTINGEN, E. Fructose-2,6-bisphosphate. Trends Biochem Sci, v. 7, p. 329-331, 1982.

14. HOUSSAY, A. B.; UGARTE, C. A. A. On the mechanism of hypertrophy of the retrolingual glands of the rat induced by incisor amputation. Archs Oral Biol, v. 14, p. 63-69, 1969.

15. HOUSSAY, A. B.; PERONACE, A. A. V.; PEREC, C. J. et al. Role of the chorda tympani in submaxillary hypertrophy by incisor amputation in the rat. Acta Physiol latinoam, v. 12, p. 153-166, 1962.

16. LLORENTE, P.; MARCO, R.; SOLS, A. Regulation of liver pyruvate and the phosphoenolpyruvate crossroads. Eur J Biochem, v. 13, p. 45-54, 1970.

17. LOWRY, O. H.; ROSEBROUGH, N. S.; FARR, A. L.; RANDALL, R. J. Protein measurement with the folin phenol reagent. J Biol Chem, v. 193, p. 265-275, 1951.

18. MANSOUR, T. E. Studies on heart phosphofructokinase: purification, inhibition and activation. J Biol Chem, v. 238 , p. 2285-2292, 1963.

19. NICOLAU, J.; FERREIRA, F. D. Adenine nucleotide changes in submandibular salivary glands of rats following isoproterenol or incisor tooth amputation. Archs Oral Biol, v. 34, p. 297-300, 1989.

20. NICOLAU, J.; SASSAKI, K. T. Metabolism of carbohydrate in the major salivary glands of rats. Archs Oral Biol, v. 21, p. 659-661, 1976

21. PEREC, C. J.; HOUSSAY, A. B.; PERONACE, A. A. V. et al. Submaxillary and retrolingual gland hypertrophy by different incisor amputations in the rat. J Dent Res, v. 44, p. 683-689, 1965.

22. PILKIS, S. J.; El-MAGHRABI, M. R.; PILKIS, J. et al. Inhibition of fructose-1.6-bisphosphatase by fructose-2,6-bisphosphate. J Biol Chem, v. 256, p. 3619-3622, 1981.

23. PURICH, D. L.; FROMM, H. J.; RUDOLPH, F. B. The hexokinase: kinetics, physical and regulatory properties. Adv Enzym, v. 39, p. 249- 326, 1973.

24. SELYE, H.; VEILLEUX, R.; CANTIN, M. Excessive stimulation of salivary gland growth by isoproterenol. Science, v. 133 , p. 44-45, 1961.

25. SUGIYA, H.; FUGITA, Y.; FUKUSHIMA, E. et al. Fructose-2,6-bisphosphate dependent regulation of phosphofructokinase in rat submandibular gland. Int $\mathbf{J}$ Biochem, v. 20, p. 237-241, 1988.

26. TAKEDA, Y.; HIROSE, H.; ENOMOTO, S. Enlargement of rat submandibular salivary gland induced by a single amputation of lower incisor teeth. J Oral Pathol, v. 15, p. 327-333, 1986.

27. UGARTE, C. A. A.; HOUSSAY, A. B.; PEREC, C. J. et al. Papel de la inervacion simpatica y parasimpatica en la hipertrofia submaxilar por amputation de incisivos. Rev Asoc Odont Argent, v. 54, p. 210-216, 1966.

28. UYEDA, K. Phosphofructokinase. Adv Enzymol Relat Areas Mol Biol, v. 48, p. 193-244, 1979.

29. UYEDA, K.; RACKER, E. Regulatory mechanism in carbohydrate metabolism. Hexokinase and phosphofructokinase. J Biol Chem, v. 240, p. 4682-4688, 1965.

30. VAN SCHAFTINGEN, E.; HERS, H. G. Phosphofructokinase-2: The enzyme that forms fructose-2,6-bisphosphate from fructose-6-phosphate and ATP. Biochem Biophys Res Commun, v. 101, p. 1078-1084, 1981.

31. WELLS, H.; ZACKIN, S. J.; GOLDHABER, P. et al. Increase in weight of the submandibular salivary glands of rats following periodic amputation of the erupted portion of the incisor teeth. Am J Physiol, v. 196, p. 827-830, 1959.

32. WELLS, H.; MUNSON, P. L. Experimental enlargement of the submandibular salivary glands of rats. Am J Physiol, v. 199, p. 63-66, 1960.

33. WELLS, H.; PERONACE, A. A. V. Functional hypertrophy and atrophy of the salivary glands of rats. Am $\mathbf{J}$ Physiol, v. 207, p. 313-318, 1964.

34. WILSON, J. E. Brain hexokinase. A proposed relation between soluble-particulate distribution and activity in vivo. J Biol Chem, v. 243, p. 3640-3547, 1968. 